\title{
Mesenteric cystic lymphangioma presenting as acute peritonitis
}

\author{
Torbielowata postać naczyniaka chłonnego krezki okrężnicy w obrazie ostrego \\ zapalenia otrzewnej
}

\author{
Jacek Hermann¹, Donata Jurczyszyn², Przemysław Majewski², Jacek Szmeja1 ${ }^{1}$, Michał Drews ${ }^{1}$ \\ ${ }^{1}$ Department of General, Gastrointestinal and Endocrinologic Surgery, University of Medical Sciences, Poznan, Poland \\ 2Department of Clinical Pathology, University of Medical Sciences, Poznan, Poland
}

Przegląd Gastroenterologiczny 2011; 6 (1): 51-54

DOI: $10.5114 /$ pg.2011.20107

Key words: lymphangioma, acute abdomen.

Słowa kluczowe: naczyniak chłonny, ostry brzuch.

Address for correspondence: Jacek Hermann, MD, PhD, Department of General, Gastrointestinal and Endocrinologic Surgery, University of Medical Sciences, Przybyszewskiego 49, 60-355 Poznan, tel. +48 61869 12 75, fax +48 61869 16 84, e-mail: jacekhermann@gmail.com

\begin{abstract}
The authors present a 25-year-old female patient who underwent laparotomy for emergent indications due to acute peritonitis in the course of septic cystic transverse mesocolonic lymphangioma. Such a lesion can be classified as a benign neoplasm or as a congenital anomaly. These tumours are more prevalent in children, with a male preponderance. They are most commonly located within soft tissues of the neck. Peritoneal cavity involvement is less then $5 \%$. Then, small bowel mesentery or mesocolon are the most frequently affected sites of the abdominal cavity. Chronic, partial intestinal obstruction is a major clinical manifestation of mesenteric lymphangioma. Acute abdomen presentation of the disease is uncommon and it can be caused by haemorrhage, perforation or torsion of a cyst or infection. The optimal treatment is radical excision of the lesion.
\end{abstract}

\section{Introduction}

Hyperplasia of lymphatic tissue can form lymphangioma which is classified as a benign neoplasm or as a congenital anomaly. Such lesions can be divided into three types, including simple capillary lymphangioma, which grows within the skin, and cavernous or cystic lesions located in deeper soft tissues of the human body [1]. Cystic lymphangioma shows a multilocular thinwalled cystic mass. It is composed of dilated lymphatic vessels of various sizes that contain serous, serous and bloody, or chylous fluid. It has an endothelial lining with connective tissue and smooth muscle fibres like a typical lymphatic vessel [2]. These tumours are more preva-

\section{Streszczenie}

Autorzy przedstawiają opis przypadku 25-letniej chorej, która przebyła laparotomię z wskazań pilnych z powodu ostrego zapalenia otrzewnej na skutek zakażenia rzadko występującego torbielowatego naczyniaka chłonnego wywodzącego się z krezki poprzecznicy. Naczyniak limfatyczny jest to rozrost naczyń chłonnych, który możemy sklasyfikować jako nowotwór niezłośliwy lub zaburzenie rozwojowe. Tego typu zmiany są najczęściej spotykane u chłopców. Lokalizują się zwykle w tkankach miękkich szyi. W jamie otrzewnej występuje mniej niż 5\% naczyniaków chłonnych. Wywodzą się one głównie z krezki jelita cienkiego bądź okrężnicy. Manifestują się klinicznie głównie w postaci przewlekłej niedrożności jelit. Rzadko spotyka się ostre objawy choroby, spowodowane krwawieniem, przedziurawieniem, skręceniem lub zakażeniem torbieli. Wyleczenie naczyniaka jest możliwe wyłącznie poprzez całkowite wycięcie zmiany.

lent in children, with a male preponderance. They are located within soft tissues of the neck in about $90 \%$ of cases and they can occasionally descend into the superior mediastinum. The bowel mesentery, retroperitoneal space and major omentum are less frequent involvements of that lesion [3]. Clinical presentation of mesenteric lymphangioma depends on diameter and location of the lesion as well. The cyst remains asymptomatic for a long period of time until it becomes large. Chronic, partial intestinal obstruction is a major clinical manifestation of the disease. Acute abdomen presentation of mesenteric cystic lymphangioma is unusual. Diagnosis of the disease is established following postoperative 
histopathological assessment in most cases. Even during the operation, the nature of the lesion is in doubt. This difficulty in diagnosis is due to the rarity of the disease and the lack of awareness of that among doctors as well [4].

The aim of the study was to present a female patient who was qualified for emergent laparotomy due to acute peritonitis in the course of septic cystic transverse mesocolonic lymphangioma diagnosed finally according to the postoperative histopathological examination.

\section{Case report}

A 25-year-old female patient was admitted to the clinic on 4 February 2010 because of acute peritonitis. Abdominal pains localized in the epigastrium and umbilical regions on the left side and pyrexia to $38^{\circ} \mathrm{C}$ occurred abruptly two days earlier in the morning. Abdominal examination revealed an immovable, soft, tender, oval and ballotable mass in the left side of the abdomen. The abdomen was tender in that region, with peritoneal signs. A computed tomography scan of the abdomen showed a $7.5 \times 10.5 \times 12.5 \mathrm{~cm}$ encapsulated, thin-walled collection of dense fluid with multiple septa in its lower part located in the epigastrium and umbilical regions on the left side. Thickness of the wall ranged from 2 to $6 \mathrm{~mm}$. A small amount of fluid in the free peritoneal cavity was found. Adjacent structures were not infiltrated by the lesion (fig. 1). Blood tests revealed elevated level of CRP to $189 \mathrm{mg} / \mathrm{l}$ (normal: $\leq 5)$ and anaemia. After preliminary preparation and administration of antibiotics, i.e. amoxicillin with clavulanic acid, the patient underwent radical excision of a yellowish, thin-walled and multilocu- lar cyst $10 \mathrm{~cm}$ in diameter. The cyst originated from the mesentery of the transverse colon near the splenic flexure and it was adherent to the wall of the colon with no signs of infiltration. Amber colour fluid from the peritoneal cavity was taken for culture, which proved positive, and Staphylococcus capitis infection sensitive to most antibiotics was diagnosed. The postoperative course was uneventful and the patient was released home on 12 February in a good general condition.

A cystic mass $5.5 \times 9.0 \times 10.0 \mathrm{~cm}$ in diameter was sent for histopathological assessment. The cyst had an endothelial lining and its wall contained oedematous connective fibrous and fat tissue, smooth muscle fibres and quite numerous dilated lymphatic vessels. Lymphocyte infiltrates were recognized within the stroma of the lesion (fig. 2, 3). Cystic lymphangioma was finally diagnosed according to the macro- and microscopic examination. Histochemical methods were used to confirm the presence of smooth muscle fibres (SMA+) (fig. 4) and endothelium (CD $34+$ ) (fig. 5) within the cystic wall.

\section{Discussion}

The authors present a young female adult patient who underwent laparotomy for emergent indications due to acute peritonitis in the course of septic cystic transverse mesocolonic lymphangioma. The peritoneal cavity is a location of such lesions in less than $5 \%$ of cases. Although lymphangiomas can occur in the retroperitoneal space or in the major omentum, the small bowel mesentery and mesocolon are the most common abdominal locations of the disease due to the abundant lymphatic network [3]. These tumours are more prevalent in chil-
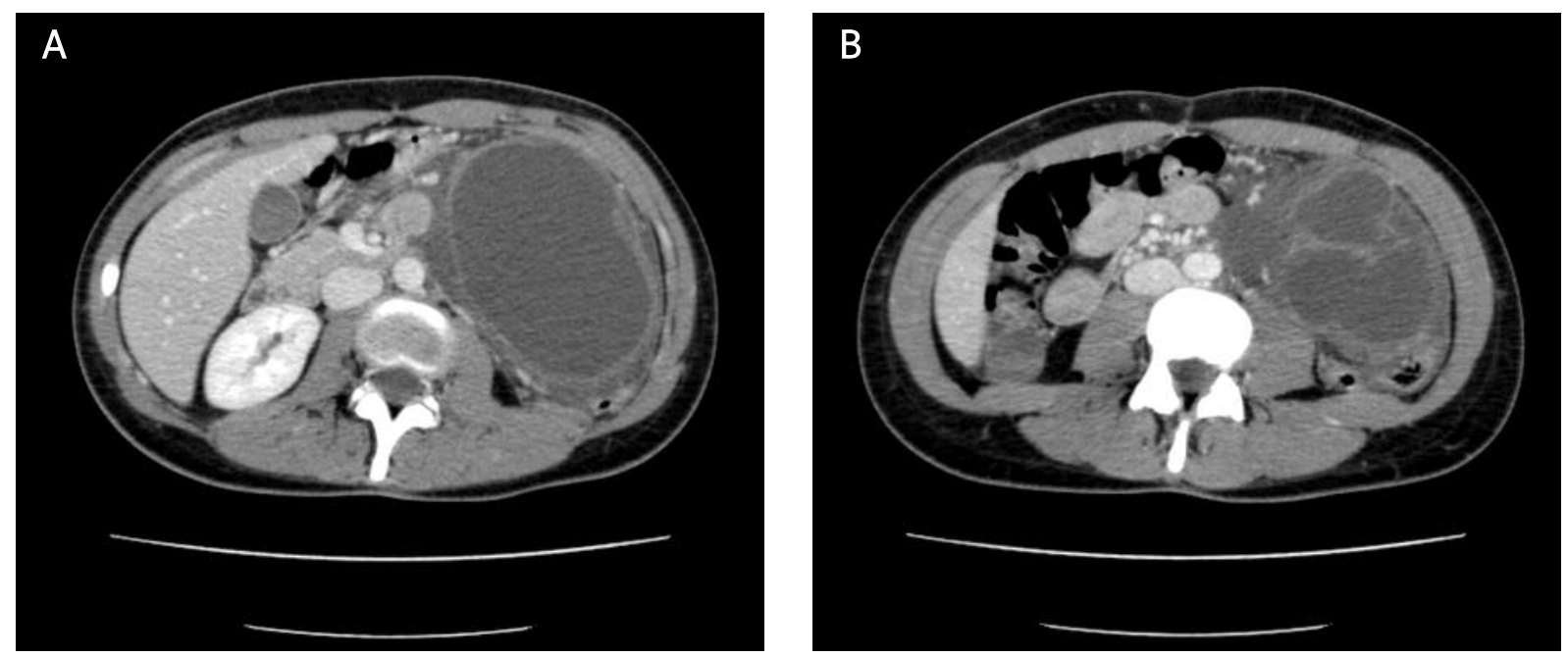

Fig. 1. Computed tomography: encapsulated, thin-walled collection $7.5 \times 10.5 \times 12.5 \mathrm{~cm}$ in diameter (A) of dense fluid with septa in its lower part (B)

Ryc. 1. Tomografia komputerowa: otorbiony cienkościenny zbiornik o wymiarach $7,5 \times 10,5 \times 12,5 \mathrm{~cm}(\mathrm{~A})$ z przegrodami w jego dolnych partiach, zawierający gęstą, płynną treść (B) 


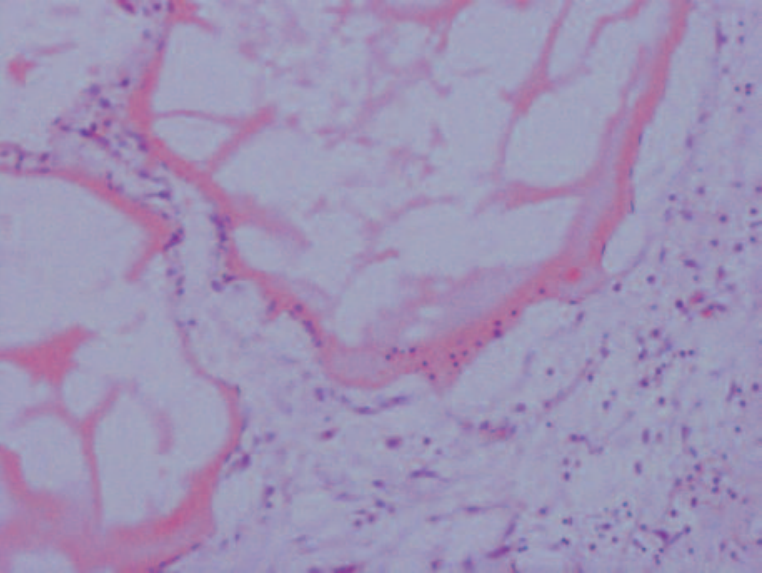

Fig. 2. Fragments of oedematous fibrous tissue elements and distended lymph vessels. H\&E $100 \times$ Ryc. 2. Fragment obrzękniętej tkanki łącznej włóknistej i poszerzone naczynia limfatyczne. $H \& E 200 x$

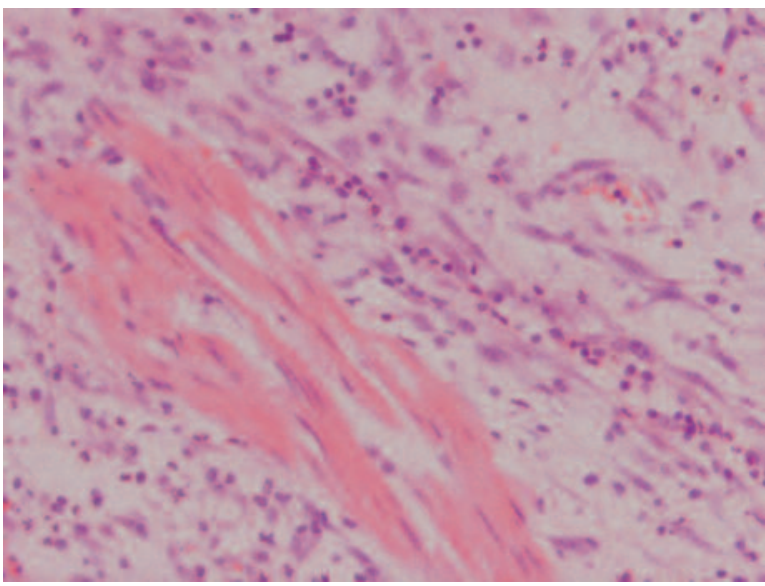

Fig. 3. Cyst wall contains smooth muscle elements H\&E $200 \times$

Ryc. 3. Włókna mięśniówki w ścianie torbieli. $H \& E 200 \times$

dren, with a male preponderance, and they are diagnosed usually before 5 years of age $[5,6]$. Diagnosis of the disease is established following postoperative histopathological assessment in most cases. Even during the operation, the nature of the lesion is in doubt. This difficulty in diagnosis is due to the rarity of the disease and to the lack of awareness of that among doctors as well $[4,7]$.

The cause of the lesions is probably either sequestration of lymphatic tissue or appearance of pathological connections between the lymphatic and venous systems during embryological development [8]. However, it is suggested that abdominal trauma or radiation therapy may lead to formation of secondary lymphangiomas [5].

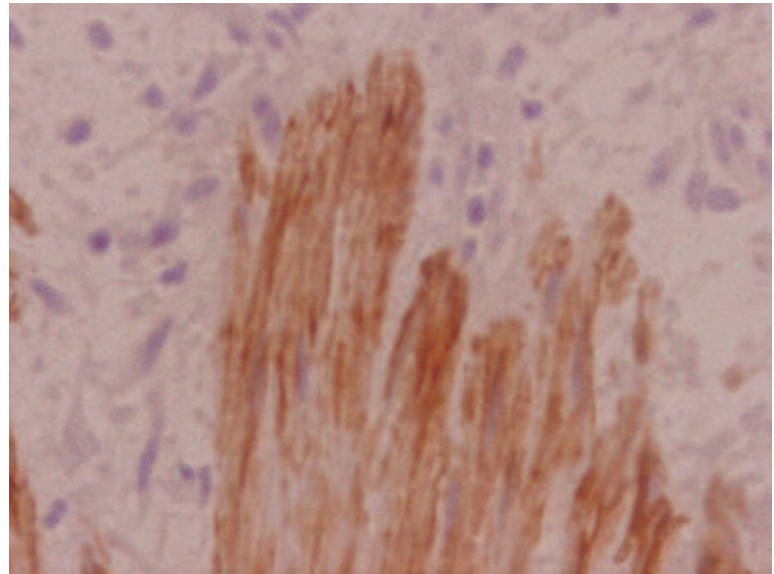

Fig. 4. Positive desmin expression $400 \times$ Ryc. 4. Dodatnia reakcja z przeciwciatem przeciw desminie. $400 \times$

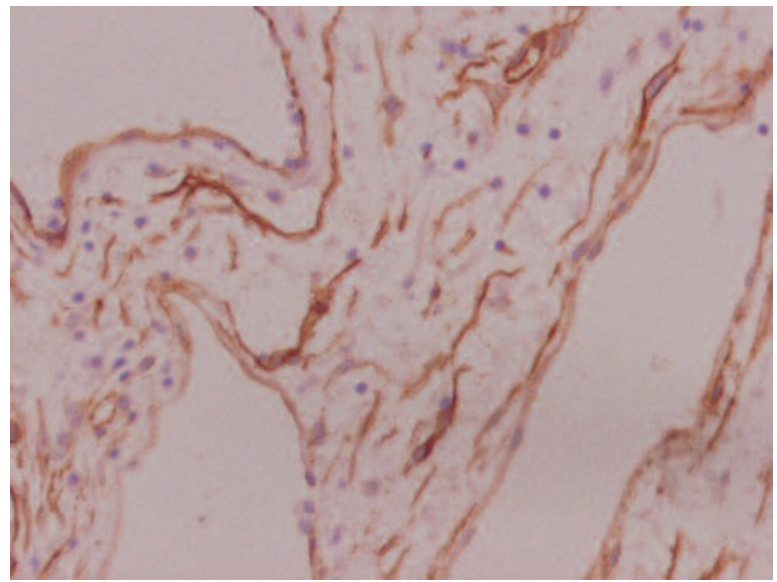

Fig. 5. Positive CD34 expression $400 \times$

Ryc. 5. Dodatnia reakcja z przeciwciatem przeciw CD 34. $400 \times$

Development of a large, multilocular cystic mass with endothelial lining and smooth muscle fibres within the cystic wall is typical of mesenteric lymphangiomas. There are different lesions of the mesentery which also form large cysts, such as intestinal duplication and benign cystic mesothelioma. Although both lesions may contain smooth muscle fibres within their wall, they have either glandular or mesothelial lining respectively [9].

Mesenteric cystic lymphangioma remains asymptomatic for a long period of time until the mass grows large. Then, the lesion presents as a chronic partial intestinal obstruction in most cases. Potential symptoms are abdominal distension and pain, nausea and vomiting, diarrhoea and/or constipation. Acute 
abdomen presentation of the disease is uncommon and it can be caused by haemorrhage, perforation or torsion of a cyst, or infection. The cause of this unusual presentation is likely infection of the contents of the cyst [10, 11]. If an abdominal mass is found in a young female patient with peritoneal irritation, gynaecological complications such as ovarian cyst or tumour with torsion, perforated ovarian cyst, ruptured tubo-ovarian abscess or ectopic pregnancy are considered in the differential diagnosis. However, radiological studies excluded the genital organs as the source of the lesion in the presented patient [12].

Mesenteric lymphangioma can be cured with radical excision of the lesion only. Extended bowel resection is necessary if the mass is closely attached to the bowel wall, and/or to the enteric vessels. Incomplete resection of the lesion can be treated with additional radiotherapy [2].

\section{References}

1. Egozi E, Ricketts R. Mesenteric and omental cysts in children Am Surgeon 1997; 63: 287-93.

2. Steyaert H, Guitard J, Moscovici J. Abdominal cystic lymphangioma in children: benign lesions that can have a proliferative course. J Ped Surg 1996; 31: 677-80.

3. Tsukada H, Takaori K, Ishiguro S. Giant cystic lymphangioma of the small bowel mesentery. Surg Today 2002; 32: 734-7.

4. de Perrot M, Rostan O, Morel P. Abdominal lymphangioma in adults and children. Br J Surg 1998; 85: 395-7.

5. Chen CW, Hsu SD, Lin CH. Cystic lymphangioma of the jejunal mesentery in an adult. World J Gastroenterol 2005; 11: 5084-6.

6. Caro P, Mahboubi S, Faerber E. Computed tomography in the diagnosis of lymphangiomas in children. Clin Imag 1991; 15: 41-6.

7. Kurtz RJ, Heimann TM, Beck AR. Mesenteric and retroperitoneal cysts. Ann Surg 1986; 203: 109-12.

8. Godart S. Embriological significance of lymphangiomas. Arch Dis Child 1966; 41: 204-6.

9. Ros PR, Olmstead WW, Moser RP Jr., et al. Mesenteric and omental cysts. Histologic classification with imaging corelation. Radiology 1987; 164: 327-32.

10. Okur H, Kucukaydin M, Ozokutan B. Mesenteric, omental and retroperitoneal cysts in children. Eur J Surg 1997; 163: 673-7.

11. Hornick JL, Fletcher CD. Intraabdominal cystic lymphangiomas obscured by marked superimposed reactive changes: clinicopathological analysis of a series. Hum Pathol 2005; 36: 426-32.

12. Tamai K, Koyama T, Togashi K. MR features of ectopic pregnancy. Eur Radiol 2007; 17: 3236-46. 